\title{
26. CARBON AND NITROGEN PROFILES IN DEEP-SEA SEDIMENTS: NEW EVIDENCE FOR BACTERIAL DIAGENESIS AT GREAT DEPTHS OF BURIAL
}

\author{
Douglas W. Waples, Department of Chemistry and Geochemistry, Colorado School of Mines, Golden \\ and \\ Jon R. Sloan, Department of Geology, University of California at Davis
}

\begin{abstract}
The sediments penetrated on Leg 58 of the Deep Sea Drilling Project in the Philippine Sea represent long periods of geologic time during which depositional conditions apparently remained very constant.

Organic carbon and nitrogen contents of the sediments decrease with increasing depth of burial, before leveling off at minimum values of about 0.05 to 0.10 per cent and 0.01 per cent, respectively. The depth at which the minimum values are reached varies from site to site, but ages of sediments corresponding to the minima are all about $5 \mathrm{~m}$.y.

We infer that slow bacterial diagenesis is responsible for the gradual depletion of organic carbon and nitrogen. It is likely that the rate of bacterial metabolism is controlled by the rate of diffusion of electron acceptors within the sediments.

These results suggest that bacterial ecosystems in deep-water sediments play a much more important role in diagenesis than has previously been thought.
\end{abstract}

\section{INTRODUCTION}

The quantity and chemical composition of organic material in sediments are strongly affected by many preand post-depositional processes. Among the identified factors which affect organic material are source, distance and mode of transport, bacterial and non-bacterial oxidation, water depth, sediment $E h$, level of photosynthetic activity, and scavenger activity. In nature, most of these factors vary independently, so that the effects of a single variable cannot be studied readily.

The sediments recovered on DSDP Leg 58 in the Philippine Sea are unusual in that they are an excellent example of a system in which post-depositional effects can be isolated from other variables. Long portions of the sections penetrated are either hemipelagic (Sites 442, 443, and 444) or pelagic (Sites 445 and 446). Within these very uniform sequences, the quantity of organic matter is consistently very low (less than $0.5 \%$ organic carbon). The organic matter probably arrived in the sediments in two ways: adsorbed on clay particles, or attached to the tests of microplankton.

There is no evidence of any detrital organic debris within the pelagic and hemipelagic sequences. There are no organic-rich layers, which suggests that plankton blooms did not play a significant role in the preservation of organic matter. The only interruptions in the monotonous hemipelagic and pelagic sequences are volcanicash layers; there are also varying proportions of admixed volcanic glass in the clays. Land sources for inorganic detritus seem to have been rather distant throughout the time of deposition of these sediments. Water depth was fairly constant during this time at Sites 442,443 , and 444 , as evidenced by an apparent maintenance of the sediment/water interface near the carbonate-compensation depth (CCD).

The rain of organic material onto the sea floor during deposition of these sediments appears to have been very constant in intensity, chemical composition, and mode of transport. We therefore conclude that any significant variations in the nature of the organic material preserved in the sediments are due to post-depositional processes.

\section{CHANGES IN KEROGEN WITH DEPTH}

Nitrogen and organic carbon contents of sediments from the five Leg 58 sites were measured by the methods described in Appendix 1. Data are reported in Tables 1 through 5. The organic-carbon contents of the sediments are plotted in Figure 1 as a function of depth. Because of the uniformity of conditions under which each sedimentary sequence was deposited, there is very little data scatter, even though the organic-carbon contents are extremely low. All five curves show the same general trend: organic contents near the surface are the highest in the section, attaining values up to 0.5 per cent. Organic carbon diminishes with depth, reaching minimum values of about 0.05 to 0.10 per cent at depths of 60 to 250 meters, below which it remains constant. The curve of organic-carbon depletion for Site 446 is truncated at the top of the section (Figure 1) because Pleistocene sediments were not recovered at that site. The youngest sediments recovered were estimated to be about 2 m.y. old (Site 446 report, this volume). 
TABLE 1

Organic Carbon and Nitrogen, Site 442 Sediments

\begin{tabular}{|c|c|c|c|c|}
\hline $\begin{array}{c}\text { Sample } \\
(\text { Interval in } \mathrm{cm})^{\mathrm{a}}\end{array}$ & $\begin{array}{l}\text { Sub-Bottom } \\
\text { Depth } \\
\text { (m) }\end{array}$ & $\begin{array}{c}C_{\text {org }} \\
(\%)\end{array}$ & $\begin{array}{l}\mathrm{N} \\
(\%)\end{array}$ & $\begin{array}{c}\mathrm{C} / \mathrm{N} \\
\text { (atomic) }\end{array}$ \\
\hline $442 \mathrm{~A}-2-3,10-11$ & 12.6 & 0.45 & 0.05 & 10.3 \\
\hline $3-1$ to $3-6$ & 23.5 & 0.31 & 0.038 & 9.6 \\
\hline $4-3,10-11$ & 31.6 & 0.32 & 0.05 & 7.1 \\
\hline $6-3,10-11$ & 50.6 & 0.31 & 0.05 & 7.4 \\
\hline $7-3$ & 60.8 & 0.26 & 0.035 & 8.6 \\
\hline $8-1,68-70$ & 67.2 & 0.58 & 0.06 & 12.2 \\
\hline $10-1$ to $10-6$ & 90.0 & 0.22 & 0.036 & 7.0 \\
\hline $11-1$ to $11-3$ & 97.3 & 0.31 & 0.036 & 10.1 \\
\hline $12-1$ to $12-5$ & 108.8 & 0.31 & 0.037 & 9.8 \\
\hline $13-2,80-82$ & 116.3 & 0.17 & 0.027 & 7.5 \\
\hline $14-3,35-36$ & 126.9 & 0.19 & 0.05 & 4.5 \\
\hline $15-1$ to $15-6$ & 137.5 & 0.10 & 0.028 & 4.2 \\
\hline $16-2,30-31$ & 144.3 & 0.08 & 0.02 & 5.2 \\
\hline $19-3,5-6$ & 174.3 & 0.13 & 0.03 & 5.1 \\
\hline $21-1,10-11$ & 190.1 & 0.14 & 0.04 & 4.3 \\
\hline $29-3,4-6$ & 269.0 & 0.06 & 0.02 & 4.1 \\
\hline $442 \mathrm{~B}-2, \mathrm{CC}$ & $286.5^{\mathrm{b}}$ & 0.06 & 0.02 & 2.9 \\
\hline $3-2,33-34$ & $289.8^{b}$ & 0.05 & 0.01 & 4.8 \\
\hline $442 \mathrm{~A}-31-1,10-11$ & 285.1 & 0.12 & 0.04 & 3.5 \\
\hline $31-1,30-32$ & 287.3 & 0.01 & $<0.01$ & n.d. \\
\hline $442 \mathrm{~B}-9, \mathrm{CC}$ & $352.8^{\mathrm{b}}$ & 0.06 & 0.02 & 4.1 \\
\hline
\end{tabular}

${ }^{\mathrm{a} C}$ Composite samples indicated by core sections only.

bDepths for Holes A and B cannot be compared directly; the samples in this table are listed in correct stratigraphic sequence.

Although the depths at which organic-carbon content levels off are variable from site to site, this minimum seems to occur in sediments of approximately the same age at each site. Figure 1 also shows sediment ages (determined by micropaleontology; site reports, this volume). It can be seen readily that minimum organiccarbon contents are reached in about $5 \mathrm{~m}$.y. Because there is no evidence that the Pliocene and Pleistocene sediments were deposited under conditions different from those prevailing during the Miocene, the decrease in organic-carbon content appears to be a consistent and predictable result of diagenesis in these deep-sea sediments.

The rate of decrease of organic carbon appears to follow first-order kinetics. Figure 2 shows a semi-log plot of organic carbon versus time for the samples from Site 444; results from the other sites are similar. Firstorder rate constants, $k$, calculated from the slopes of the lines in the semi-log plots are tabulated for the five sites in Table 6. The methodology used in these calculations is explained in Appendix 2. The rate constants thus obtained are similar, varying among themselves by about a factor of 2.

The pre-Pliocene part of the section at each site shows no further decrease in organic carbon. The calculated rate constant in this portion of the section is therefore zero.

Nitrogen content also decreases with increasing burial depth, as shown in Figure 3. Data scatter is somewhat greater than for organic carbon, because nitrogen contents of these sediments are very low, and
TABLE 2

Organic Carbon and Nitrogen, Site 443 Sediments

\begin{tabular}{|c|c|c|c|c|}
\hline $\begin{array}{c}\text { Sample } \\
\text { (Interval in } \mathrm{cm} \text { ) }\end{array}$ & $\begin{array}{l}\text { Sub-Bottom } \\
\text { Depth } \\
\text { (m) }\end{array}$ & $\begin{array}{l}\mathrm{C}_{\text {org }} \\
(\%)\end{array}$ & $\begin{array}{c}\mathrm{N} \\
(\%)\end{array}$ & $\begin{array}{c}\mathrm{C} / \mathrm{N} \\
\text { (atomic) }\end{array}$ \\
\hline $443-1-4,84-86$ & 5.4 & 0.34 & .041 & 9.6 \\
\hline $2-4,72-74$ & 12.2 & 0.41 & .045 & 10.6 \\
\hline $4-2,23-24$ & 27.7 & 0.34 & .041 & 9.6 \\
\hline $6-4,58-59$ & 50.1 & 0.41 & .048 & 9.8 \\
\hline $8-4,111-112$ & 69.6 & 0.25 & .039 & 7.3 \\
\hline $10-4,45-46$ & 88.0 & 0.17 & .033 & 6.0 \\
\hline $11-4,125-126$ & 98.3 & 0.22 & .037 & 7.0 \\
\hline $14-5,65-66$ & 127.6 & 0.15 & .031 & 5.6 \\
\hline $17-4,27-28$ & 154.3 & 0.15 & .029 & 5.9 \\
\hline $18-3,29-30$ & 162.3 & 0.15 & .032 & 5.4 \\
\hline $21-2,34-36$ & 189.3 & 0.12 & .030 & 4.7 \\
\hline $22-2,104-106$ & 199.5 & 0.10 & .027 & 4.3 \\
\hline $23-4,40-41$ & 211.4 & 0.08 & .021 & 4.6 \\
\hline $24-4,117-118$ & 221.7 & 0.09 & .023 & 4.5 \\
\hline $25-3,26-27$ & 228.8 & 0.09 & .021 & 5.0 \\
\hline $26-2,115-116$ & 238.2 & 0.08 & .071 & 5.3 \\
\hline $28-2,60-61$ & 256.6 & 0.09 & .024 & 4.3 \\
\hline $30-1,120-121$ & 274.2 & 0.07 & .021 & 4.2 \\
\hline $31-4,59-60$ & 287.6 & 0.07 & .018 & 4.6 \\
\hline $32-1,131-132$ & 293.3 & 0.08 & .017 & 5.3 \\
\hline $33-3,33-34$ & 304.8 & 0.05 & .009 & 6.9 \\
\hline $34-4,65-66$ & 316.2 & 0.09 & .027 & 3.7 \\
\hline $35-2,23-24$ & 322.2 & 0.07 & .017 & 4.6 \\
\hline $36-4,92-93$ & 335.4 & 0.09 & .015 & 7.2 \\
\hline $37-1,133-134$ & 340.8 & 0.08 & .016 & 5.4 \\
\hline $39-1,111-112$ & 359.6 & 0.13 & .021 & 7.1 \\
\hline $40-2,63-64$ & 370.1 & 0.08 & .023 & 3.9 \\
\hline $41-1,58-59$ & 378.1 & 0.11 & .019 & 6.5 \\
\hline $42-2,7-8$ & 388.6 & 0.07 & .013 & 6.0 \\
\hline $43-2,87-88$ & 398.9 & 0.10 & .020 & 6.0 \\
\hline $45-2,92-93$ & 417.9 & 0.08 & .020 & 4.9 \\
\hline $46-1,72-73$ & 425.7 & 0.22 & .014 & 18.5 \\
\hline $47-1,39-40$ & 434.9 & 0.08 & .019 & 4.7 \\
\hline
\end{tabular}

therefore rather susceptible to random analytical error. The trends for all five sites are unmistakable, however. Unlike organic-carbon content, nitrogen content continues to decrease throughout the section. This trend is particularly well displayed in the sediments at Sites 445 and 446 , which represent about 45 million years of diagenesis.

Semi-log plots of nitrogen loss were made, and a typical result, for Site 443, is shown in Figure 4. The kinetic data suggest that there is an important difference between the behavior of carbon and nitrogen in these sediments. Figure 4 can be interpreted to mean that there are two distinct mechanisms operative in nitrogen loss. The first type of reaction, with a first-order rate constant $k_{N_{l}}$, occurs during the first 4 or $5 \mathrm{~m} . \mathrm{y}$. of burial. This is about the same time interval during which carbon loss occurs. The second type of reaction, with a first-order rate constant $k_{N_{2}}$, is slower. This latter reaction becomes important when the first reaction ceases, and continues throughout the time represented by the oldest sediments penetrated by Leg 58 drilling.

Carbon/nitrogen ratios, a commonly used parameter in describing kerogens, are also informative for these 
TABLE 3

Organic Carbon and Nitrogen, Site 444 Sediments

\begin{tabular}{|c|c|c|c|c|}
\hline $\begin{array}{c}\text { Sample } \\
\text { (Interval in } \mathrm{cm} \text { ) }\end{array}$ & $\begin{array}{l}\text { Sub-Bottom } \\
\text { Depth } \\
\text { (m) }\end{array}$ & $\begin{array}{l}\mathrm{C}_{\text {org }} \\
(\%)\end{array}$ & $\begin{array}{c}\mathrm{N} \\
(\%)\end{array}$ & $\begin{array}{c}\mathrm{C} / \mathrm{N} \\
\text { (atomic) }\end{array}$ \\
\hline $444-1, \mathrm{CC}, 0-1$ & 5.5 & 0.16 & .020 & 8.7 \\
\hline $1, \mathrm{CC}, 25$ & 5.7 & 0.19 & .021 & 10.4 \\
\hline $2-1,16-18$ & 6.2 & 0.27 & .040 & 7.9 \\
\hline $2-1,139-141$ & 7.4 & 0.32 & .048 & 7.7 \\
\hline $2-3,47-48$ & 9.5 & 0.30 & .046 & 7.6 \\
\hline $2-5,106-107$ & 13.1 & 0.23 & .040 & 6.9 \\
\hline $3-1,69-70$ & 16.2 & 0.21 & .030 & 8.3 \\
\hline $3-3,79-80$ & 19.3 & 0.24 & .033 & 8.5 \\
\hline $4-2,83-84$ & 27.3 & 0.15 & .033 & 5.2 \\
\hline $5-2,44-45$ & 36.4 & 0.12 & .031 & 4.7 \\
\hline $6-1,84-85$ & 44.8 & 0.12 & .031 & 4.7 \\
\hline $7-3,36-37$ & 56.9 & 0.06 & .024 & 2.9 \\
\hline $8-1,47-48$ & 63.5 & 0.05 & .009 & 7.2 \\
\hline $9-1,71-72$ & 73.2 & 0.09 & .020 & 5.0 \\
\hline $10-2,110-111$ & 84.6 & 0.06 & .024 & 3.1 \\
\hline $444 \mathrm{~A}-1-6,83-84$ & 90.3 & 0.07 & .024 & 3.4 \\
\hline $2-4,15-16$ & 96.2 & 0.07 & .024 & 3.6 \\
\hline $3-2,91-92$ & 103.4 & 0.06 & .019 & 3.9 \\
\hline $3-5,91-92$ & 107.9 & 0.07 & .021 & 4.0 \\
\hline $6-2,20-21$ & 131.2 & 0.06 & .026 & 2.7 \\
\hline $7-1,60-61$ & 139.6 & 0.05 & .029 & 2.1 \\
\hline $8-1,65-66$ & 149.1 & 0.06 & .029 & 2.4 \\
\hline $9-2,62-64$ & 160.1 & 0.06 & .017 & 4.3 \\
\hline $10-2,19-20$ & 169.2 & 0.03 & .007 & 5.3 \\
\hline $11-1,81-83$ & 177.8 & 0.05 & .015 & 3.6 \\
\hline $12-2,82-83$ & 188.8 & 0.05 & .017 & 3.7 \\
\hline $13-2,44-45$ & 197.9 & 0.06 & .013 & 5.2 \\
\hline $14-2,45-46$ & 207.4 & 0.05 & .014 & 4.6 \\
\hline $14-4,45-46$ & 210.4 & 0.03 & .004 & 7.7 \\
\hline $15-1,70-71$ & 215.7 & 0.03 & .006 & 6.1 \\
\hline $15-3,76-77$ & 218.7 & 0.08 & .020 & 4.5 \\
\hline $16-1,38-39$ & 224.9 & 0.06 & .016 & 4.3 \\
\hline $16-3,62-63$ & 228.1 & 0.02 & .004 & 7.0 \\
\hline $17-1,19-20$ & 230.2 & 0.04 & .003 & 15.2 \\
\hline $21-1,0-1$ & 253.0 & 0.09 & .021 & 4.8 \\
\hline $21-1,5-6$ & 253.1 & 0.14 & .016 & 9.9 \\
\hline $21-1,13$ & 253.1 & 0.08 & .014 & 6.9 \\
\hline $21-1,15-16$ & 253.2 & 0.12 & .006 & 22.2 \\
\hline $21-1,18-19$ & 253.2 & 0.08 & .011 & 8.4 \\
\hline $21-1,28-29$ & 253.3 & 0.04 & .002 & 20.6 \\
\hline $21-1,38-39$ & 253.4 & 0.06 & .002 & 41.1 \\
\hline $21-1,73-74$ & 253.7 & 0.06 & .001 & 54.7 \\
\hline $21-1,99-100$ & 254.0 & 0.09 & .020 & 5.4 \\
\hline $21-1,113-115$ & 254.1 & 0.09 & .010 & 10.2 \\
\hline $21-1,134-135$ & 254.3 & 0.07 & .016 & 5.1 \\
\hline $21-2,5-7$ & 254.5 & 0.13 & .016 & 9.3 \\
\hline $21-2,45-47$ & 254.9 & 0.09 & .015 & 7.1 \\
\hline $22-1,18-19$ & 262.7 & 0.10 & .025 & 4.4 \\
\hline $22-1,109-110$ & 263.6 & 0.08 & .029 & 3.5 \\
\hline $22-2,1-2$ & 264.0 & 0.16 & .027 & 7.1 \\
\hline $22-2,91-93$ & 264.9 & 0.12 & .011 & 12.7 \\
\hline $22-3,82-84$ & 266.3 & 0.06 & .025 & 2.7 \\
\hline $22-7,21-22$ & 271.3 & 0.05 & .019 & 3.2 \\
\hline $23-1,54-55$ & 272.5 & 0.04 & .016 & 2.2 \\
\hline $23-1,73-74$ & 272.7 & 0.08 & .008 & 12.5 \\
\hline $23-1,80-81$ & 272.8 & 0.06 & .011 & 5.8 \\
\hline
\end{tabular}

sediments. $\mathrm{C} / \mathrm{N}$ ratios show more scatter than do either carbon or nitrogen data alone, since the errors present in each measurement augment each other when a ratio is taken (Figure 5).
TABLE 4

Organic Carbon and Nitrogen, Site 445 Sediments

\begin{tabular}{|c|c|c|c|c|}
\hline $\begin{array}{c}\text { Sample } \\
\text { (Interval in } \mathrm{cm} \text { ) }\end{array}$ & $\begin{array}{l}\text { Sub-Bottom } \\
\text { Depth } \\
\text { (m) }\end{array}$ & $\begin{array}{l}\mathrm{C}_{\text {org }} \\
(\%)\end{array}$ & $\begin{array}{l}\mathrm{N} \\
(\%)\end{array}$ & $\begin{array}{c}\mathrm{C} / \mathrm{N} \\
\text { (atomic) }\end{array}$ \\
\hline $445-1-1,0-1$ & 0.0 & 0.21 & .032 & 7.5 \\
\hline $1-1,45-46$ & 0.4 & 0.21 & .038 & 8.2 \\
\hline $1-2,125-126$ & 2.8 & 0.14 & .025 & 6.2 \\
\hline $1-6,68-69$ & 8.1 & 0.17 & .036 & 5.4 \\
\hline $2-2,46-47$ & 10.5 & 0.19 & .033 & 6.9 \\
\hline $2-3,85-86$ & 11.9 & 0.14 & .031 & 5.8 \\
\hline $3-1,95-96$ & 19.0 & 0.16 & .045 & 4.4 \\
\hline $3-4,103-104$ & 23.5 & 0.10 & .032 & 4.1 \\
\hline $3-6,103-104$ & 26.5 & 0.08 & .021 & 5.2 \\
\hline $4-2,97-98$ & 30.0 & 0.08 & .014 & 7.5 \\
\hline $5-2,52-53$ & 39.0 & 0.08 & .024 & 4.4 \\
\hline $6-2,109-110$ & 49.1 & 0.09 & .024 & 5.0 \\
\hline $7-5,75-77$ & 62.8 & 0.08 & .021 & 5.1 \\
\hline $8-2,66-67$ & 67.7 & 0.08 & .027 & 4.1 \\
\hline $9-1,21-22$ & 75.2 & 0.07 & .022 & 3.7 \\
\hline $10-4,60-61$ & 89.6 & 0.07 & .014 & 6.2 \\
\hline $11-3,106-107$ & 98.1 & 0.05 & .018 & 3.5 \\
\hline $12-2,26-27$ & 105.3 & 0.08 & .013 & 7.1 \\
\hline $13-2,75-76$ & 115.3 & 0.08 & .030 & 3.1 \\
\hline $14-2,98-99$ & 125.0 & 0.06 & .011 & 6.6 \\
\hline $15-2,64-65$ & 134.1 & 0.05 & .021 & 3.0 \\
\hline $16-1,70-71$ & 142.1 & & & \\
\hline $17-2,56-57$ & 153.1 & 0.07 & .012 & 6.6 \\
\hline $18-3,89-90$ & 164.4 & 0.04 & .009 & 5.5 \\
\hline $18-3,92-93$ & 164.4 & 0.05 & .022 & 2.8 \\
\hline $21-2,36-37$ & 190.8 & 0.04 & .015 & 3.2 \\
\hline $24-2,49-50$ & 219.5 & 0.05 & .018 & 3.6 \\
\hline $28-2,90-91$ & 257.9 & 0.05 & .012 & 4.9 \\
\hline $29-2,38-39$ & 266.9 & 0.04 & .018 & 2.7 \\
\hline $30-1,47-48$ & 275.0 & 0.10 & .020 & 5.9 \\
\hline $31-2,74-75$ & 286.2 & 0.07 & .019 & 4.0 \\
\hline $32-2,70-71$ & 295.7 & 0.12 & .024 & 6.0 \\
\hline $34-2,80-81$ & 314.8 & 0.05 & .018 & 3.5 \\
\hline $36-5,75$ & 338.3 & 0.08 & .017 & 5.4 \\
\hline $37-3,23-24$ & 344.2 & 0.07 & .017 & 4.4 \\
\hline $37-4,89-90$ & 346.4 & 0.06 & .026 & 2.5 \\
\hline $38-1,139-141$ & 351.9 & 0.06 & .013 & 6.0 \\
\hline $39-1,76-77$ & 360.8 & 0.02 & .009 & 2.9 \\
\hline $40-3,76-77$ & 373.3 & 0.05 & .010 & 6.0 \\
\hline $41-4,57-58$ & 384.1 & 0.04 & .008 & 5.7 \\
\hline $42-2,46-47$ & 390.5 & 0.06 & .018 & 3.6 \\
\hline $43-2,85-86$ & 400.4 & 0.05 & .007 & 8.0 \\
\hline $46-1,60-61$ & 427.1 & 0.08 & .005 & 20.7 \\
\hline $47-3,69-70$ & 439.7 & 0.04 & .018 & 2.3 \\
\hline $48-2,110-111$ & 448.1 & 0.05 & .007 & 7.8 \\
\hline $51-2,4-5$ & 475.5 & 0.07 & .005 & 16.2 \\
\hline $54-2,85-86$ & 504.9 & 0.07 & .005 & 16.1 \\
\hline $56-2,85-86$ & 523.8 & 0.07 & .005 & 17.9 \\
\hline $58-2,49-50$ & 542.5 & 0.09 & .010 & 21.5 \\
\hline $62-6,87-88$ & 586.9 & 0.06 & .002 & 28.6 \\
\hline $64-6,111-112$ & 606.1 & 0.08 & .005 & 16.8 \\
\hline $67-1,87-88$ & 626.9 & 0.10 & .010 & 11.6 \\
\hline $69-1,90-91$ & 645.9 & 0.11 & .007 & 17.5 \\
\hline $71-2,22-23$ & 665.7 & 0.06 & .011 & 6.7 \\
\hline $71-3,80-81$ & 667.8 & 0.08 & .009 & 9.7 \\
\hline $72-1,21-25$ & 673.7 & 0.06 & .009 & 8.7 \\
\hline $73-1,104-105$ & 684.0 & 0.07 & .006 & 13.7 \\
\hline $74-1,31-32$ & 692.8 & 0.04 & .004 & 11.4 \\
\hline $75-2,145-146$ & 705.0 & 0.09 & .010 & 10.1 \\
\hline $76-2,75-76$ & 713.8 & 0.08 & .007 & 14.1 \\
\hline $77-1,74-75$ & 721.7 & 0.05 & .006 & 9.7 \\
\hline $79-4,74-75$ & 745.2 & 0.14 & .010 & 17.5 \\
\hline $80-1,74$ & 750.2 & 0.07 & .006 & 13.3 \\
\hline $81-3,93-94$ & 762.9 & 0.09 & .004 & 24.0 \\
\hline
\end{tabular}


TABLE 5

Organic Carbon and Nitrogen, Site 446 Sediments

\begin{tabular}{|c|c|c|c|c|}
\hline $\begin{array}{c}\text { Sample } \\
\text { (Interval in } \mathrm{cm} \text { ) }\end{array}$ & $\begin{array}{l}\text { Sub-Bottom } \\
\text { Depth } \\
\text { (m) }\end{array}$ & $\begin{array}{l}\mathrm{C}_{\text {org }} \\
(\%)\end{array}$ & $\begin{array}{l}\mathrm{N} \\
(\%)\end{array}$ & $\begin{array}{c}\mathrm{C} / \mathrm{N} \\
\text { (atomic) }\end{array}$ \\
\hline $446-1-1,18-19$ & 0.2 & 0.11 & .039 & 3.3 \\
\hline $1-1,105-106$ & 1.1 & 0.10 & .022 & 5.1 \\
\hline $2-1,44-45$ & 1.9 & 0.11 & .032 & 4.0 \\
\hline $3-2,89-90$ & 13.4 & 0.07 & .036 & 2.3 \\
\hline $3-6,89-90$ & 19.4 & 0.06 & .029 & 2.2 \\
\hline $4, \mathrm{CC}$ & 29.8 & 0.06 & .020 & 3.3 \\
\hline $5-3,76-77$ & 33.8 & 0.07 & .028 & 2.8 \\
\hline $6-2,82-83$ & 41.8 & 0.05 & .030 & 1.9 \\
\hline $7-2,88-89$ & 51.4 & 0.04 & .020 & 2.6 \\
\hline $8-2,68-69$ & 60.7 & 0.04 & .028 & 1.8 \\
\hline $10-2,144-145$ & 80.4 & 0.06 & .022 & 3.3 \\
\hline $12-2,75-76$ & 98.8 & 0.06 & .016 & 4.3 \\
\hline $14-4,40-41$ & 120.4 & 0.06 & .017 & 4.0 \\
\hline $16-2,30-31$ & 136.3 & 0.05 & .006 & 10.1 \\
\hline $18-1,137-138$ & 154.9 & 0.05 & .009 & 7.3 \\
\hline $20-1,66-67$ & 173.2 & 0.10 & .006 & 22.7 \\
\hline $23-2,77-78$ & 203.3 & 0.03 & .003 & 10.7 \\
\hline $26-4,19-20$ & 234.2 & 0.03 & .005 & 8.1 \\
\hline $29-1,34-35$ & 258.3 & 0.04 & .006 & 8.5 \\
\hline $31-2,89-90$ & 279.4 & 0.01 & .005 & 2.9 \\
\hline $33-2,51-52$ & 298.0 & 0.02 & .005 & 5.5 \\
\hline $36-1,53-54$ & 325.0 & 0.03 & .003 & 10.3 \\
\hline $36-5,0-1$ & 330.5 & 0.01 & .006 & 2.7 \\
\hline $38-1,100-101$ & 344.5 & 0.01 & .004 & 4.0 \\
\hline $38-3,100-101$ & 347.5 & 0.03 & .004 & 7.9 \\
\hline $39-1,70-71$ & 353.7 & 0.02 & .005 & 4.1 \\
\hline $40-2,5-6$ & 364.1 & 0.02 & .001 & 22.1 \\
\hline $41-1,125-126$ & 373.3 & 0.02 & .007 & 2.7 \\
\hline $446 \mathrm{~A}-1, \mathrm{CC}$ & 381.3 & 0.06 & n.d. & n.d. \\
\hline $2-1,50-52$ & 382.0 & 0.06 & n.d. & n.d. \\
\hline $2-1,68-70$ & 382.2 & 0.03 & n.d. & n.d. \\
\hline $446-43-1,49-50$ & 391.5 & 0.02 & .008 & 2.6 \\
\hline $446 \mathrm{~A}-3-1,58-60$ & 391.6 & 0.07 & .002 & 37.6 \\
\hline $3-2,130-132$ & 393.8 & 0.07 & .009 & 9.7 \\
\hline $446-43-2,130-131$ & 393.8 & 0.01 & .002 & 6.7 \\
\hline $43-3,4-5$ & 394.0 & 0.02 & .005 & 6.1 \\
\hline $43-3,119-120$ & 395.2 & 0.02 & .005 & 5.9 \\
\hline $43-4,0-2$ & 395.5 & 0.01 & .001 & 2.9 \\
\hline $43-4,14-15$ & 395.6 & 0.02 & .004 & 5.9 \\
\hline $446 \mathrm{~A}-9-1,16-17$ & 438.7 & 0.02 & n.d. & n.d. \\
\hline $10-5,62-64$ & 454.6 & 0.02 & n.d. & n.d. \\
\hline $12-3,105-106$ & 471.1 & 0.11 & n.d. & n.d. \\
\hline $13-3,74-75$ & 480.2 & 0.11 & n.d. & n.d. \\
\hline $16, \mathrm{CC}$ & 514.3 & 0.03 & .004 & 9.1 \\
\hline $17-2,57-59$ & 516.6 & 0.13 & .017 & 8.8 \\
\hline $18-2,50-52$ & 526.0 & 0.01 & .001 & 11.4 \\
\hline $22-1,65-66$ & 562.7 & 0.06 & .001 & 52.8 \\
\hline $22-1,109-110$ & 563.1 & 0.04 & .001 & 32.1 \\
\hline $22-1,122-123$ & 563.2 & 0.17 & .007 & 29.1 \\
\hline $23-1,60-62$ & 572.1 & 0.06 & .006 & 11.1 \\
\hline $24-1,109-110$ & 582.1 & 0.02 & .004 & 6.5 \\
\hline $24-2,70-71$ & 583.2 & 0.07 & .012 & 6.7 \\
\hline $25-3,71-72$ & 594.2 & 0.04 & .004 & 12.1 \\
\hline $25-3,93-94$ & 594.4 & 0.02 & .003 & 7.2 \\
\hline $25-3,99-100$ & 594.5 & 0.02 & .008 & 2.3 \\
\hline $26-3,70-71$ & 603.7 & 0.06 & .007 & 10.4 \\
\hline $26-3,104-105$ & 604.0 & 0.02 & .002 & 15.8 \\
\hline $28-1,23-24$ & 619.2 & 0.05 & .003 & 21.9 \\
\hline $28, \mathrm{CC}$ & 628.3 & 0.06 & .010 & 7.1 \\
\hline
\end{tabular}

The atomic $\mathrm{C} / \mathrm{N}$ ratios of the uppermost sediments are similar to those proposed for other marine sediments (Emery and Rittenberg, 1952), averaging around 10. $\mathrm{C} / \mathrm{N}$ ratios decrease significantly with increasing depth of burial, indicating that carbon is lost more rapidly than nitrogen during the first few millions of years of diagenetic change. $\mathrm{C} / \mathrm{N}$ ratios therefore decrease steadily during about the first $5 \mathrm{~m} . \mathrm{y}$. of burial. After 5 m.y., however, loss of carbon has ceased, while nitrogen depletion continues. $\mathrm{C} / \mathrm{N}$ ratios of the kerogens thus increase slightly in sediments between 5 and 15 m.y. old, and then increase more rapidly with age in sediments older than about $15 \mathrm{~m} . \mathrm{y}$. This trend is well reflected at Sites 445 and 446 , where sediments up to 45 m.y. old were analyzed.

These results are in general agreement with previous investigations (Emery and Rittenberg, 1952; Waples, 1977) which showed that $\mathrm{C} / \mathrm{N}$ ratios increase significantly as an unconsolidated marine mud is lithified. Data from these investigations suggest that this increase, at least in abyssal environments, is not steady; rather, there is an initial stage during which the $\mathrm{C} / \mathrm{N}$ ratio decreases to values of 2 to 3 , before finally increasing.

\section{INTERPRETATIONS}

There are several factors which should be considered as possible explanations for the loss of organic carbon and nitrogen with increasing depth of burial in the five analyzed sections. Among these are sedimentation rate, thermal effects, bacterial degradation, and nonbacterial oxidation.

\section{Sedimentation Rate}

Sedimentation rates determined from micropaleontological data do not correlate with organic-carbon contents within any single profile. Figure 6 , in which sedimentation rate and organic-carbon content are plotted versus depth for Site 443 , is typical and illustrative. Sedimentation rates were highest during the late Pliocene, whereas organic-carbon contents are highest in the Pleistocene. Furthermore, during the Miocene there were also periods of relatively rapid sedimentation; these periods are not reflected in the organic-carbon contents. We therefore conclude that sedimentation rates did not significantly influence the organic carbon content.

A closer comparison of the sedimentation rates for Sites 442-445, however, suggested a most interesting relationship to George Claypool (pers. comm.). There appears to be an inverse correlation between the rate constants for carbon and nitrogen loss, $k_{C}$ and $k_{N_{l}}$, and the average sedimentation rate. The data supporting this conclusion are presented in Table 7. During periods of rapid sedimentation, diagenesis of organic carbon and nitrogen apparently proceeds more slowly. This is just the reverse of the commonly accepted relationship: rates of consumption of organic matter are supposed to in- 

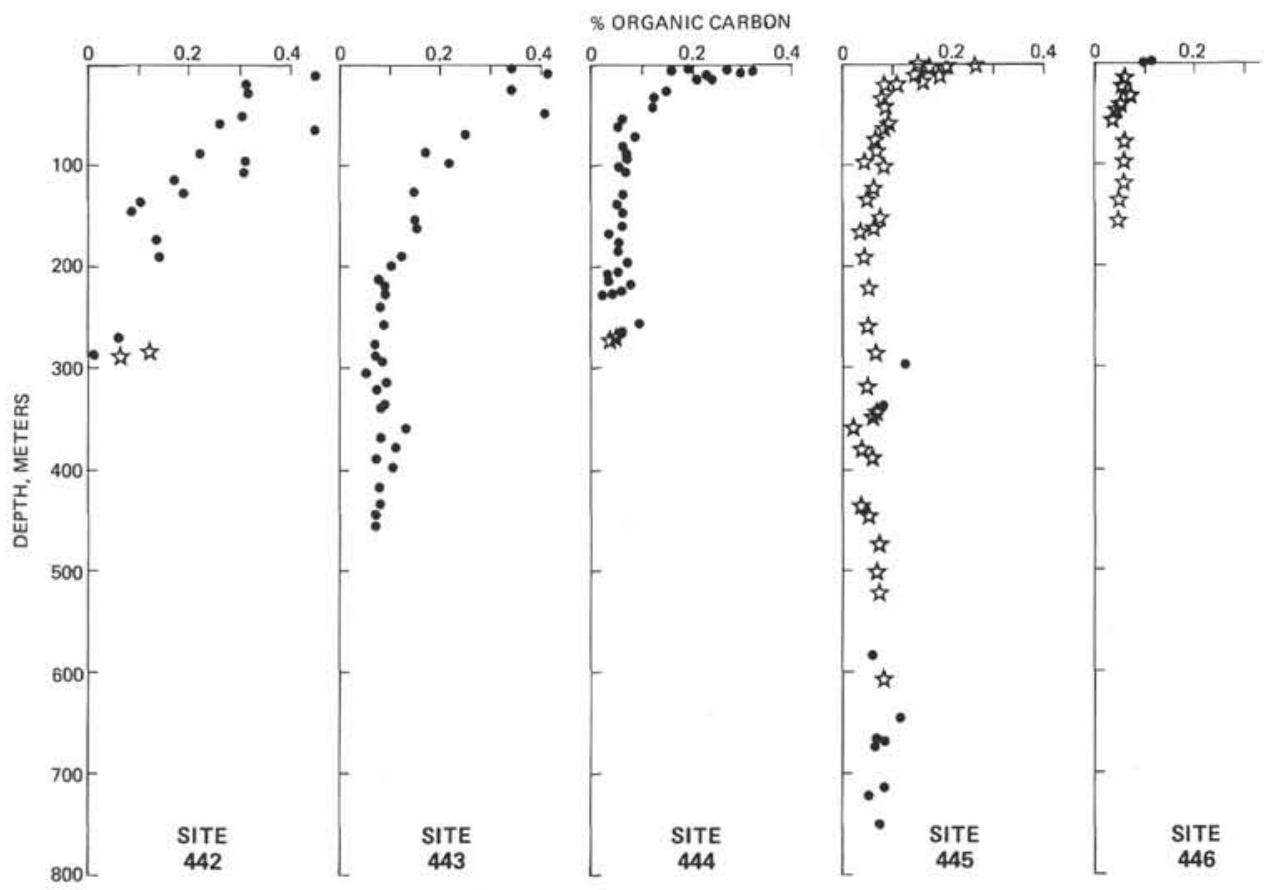

Figure 1. Organic-carbon profiles for Leg 58 sediments. Circles represent hemipelagic sediments; stars represent pelagic sediments.

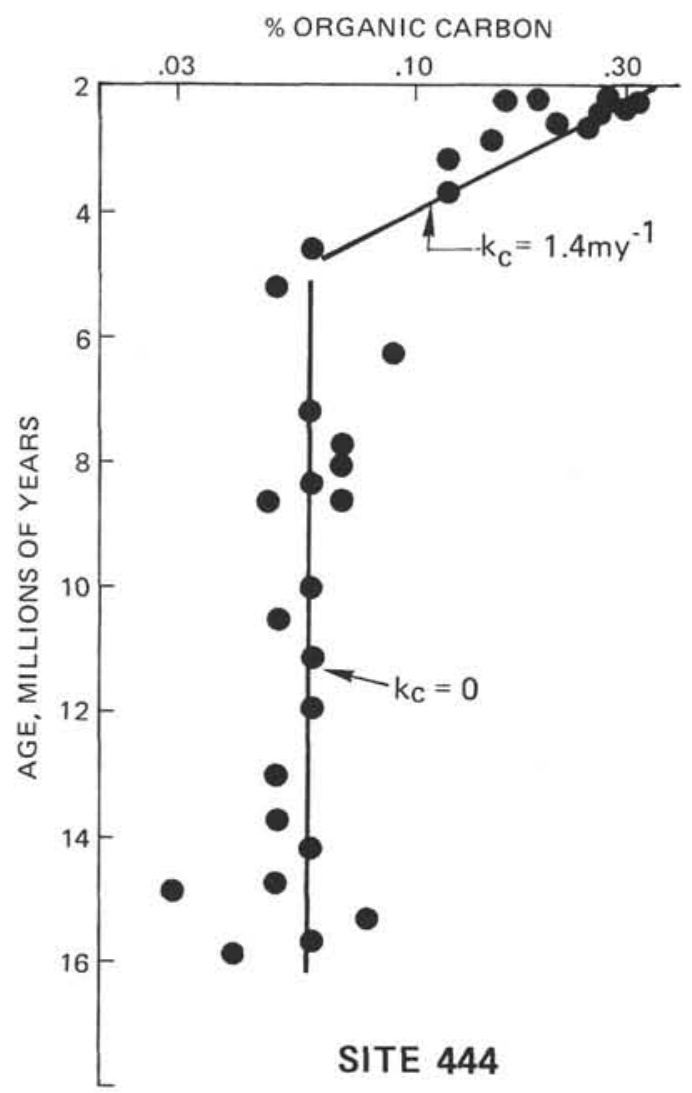

Figure 2. Semi-log kinetic plot of organic-carbon content versus sediment age for Site 444 samples.
TABLE 6

First-Order Rate Constants for Loss of Organic Carbon and Nitrogen at Leg 58 Sites

\begin{tabular}{|c|c|c|c|}
\hline \multirow[b]{2}{*}{ Site } & \multirow{2}{*}{$\begin{array}{c}\text { Carbon } \\
k_{C} \\
\left(\mathrm{~m} . \mathrm{y}^{-1}\right)\end{array}$} & \multicolumn{2}{|c|}{ Nitrogen } \\
\hline & & $\begin{array}{c}k_{N_{1}} \\
\left(\mathrm{~m} . \mathrm{y} \cdot{ }^{-1}\right)\end{array}$ & $\begin{array}{c}k_{N_{2}} \\
\left(\mathrm{~m} . \mathrm{y}^{-1}\right)\end{array}$ \\
\hline 442 & 1.0 & 0.30 & $-a$ \\
\hline 443 & 0.8 & 0.17 & 0.04 \\
\hline 444 & 1.4 & 0.34 & 0.04 \\
\hline 445 & 1.1 & 0.28 & 0.02 \\
\hline 446 & $-\mathrm{a}$ & $-a$ & 0.03 \\
\hline
\end{tabular}

${ }^{a}$ Not calculable, because of insufficient data.

crease with increasing sedimentation rate (Goldhaber and Kaplan, 1975; Toth and Lerman, 1977; Berner, 1978). This suggests that bacterial metabolism may be limited by the rate of replenishment of dissolved oxygen (or some other appropriate electron acceptor) by diffusion. Diffusion is most effective where sedimentation rates are slowest.

\section{Thermal Effects}

It is extremely unlikely that catagenetic processes have played any significant role in the post-depositional transformation of organic material, except in the immediate vicinity of basalt sills which cut some of the sediments near the bottom of the sedimentary section. No samples of such sediments were included in the pres- 

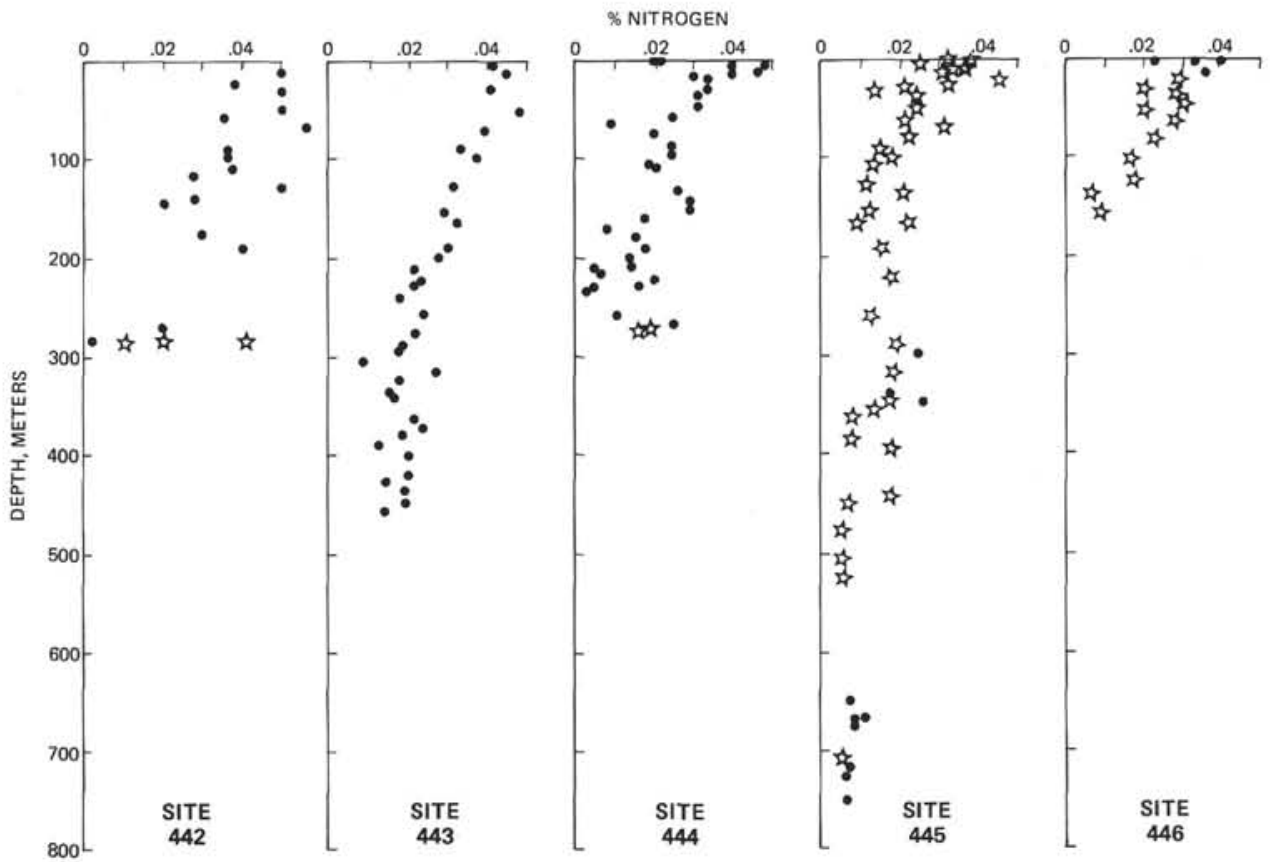

Figure 3. Nitrogen profiles for Leg 58 sediments. Circles represent hemipelagic sediments; stars represent pelagic sediments.

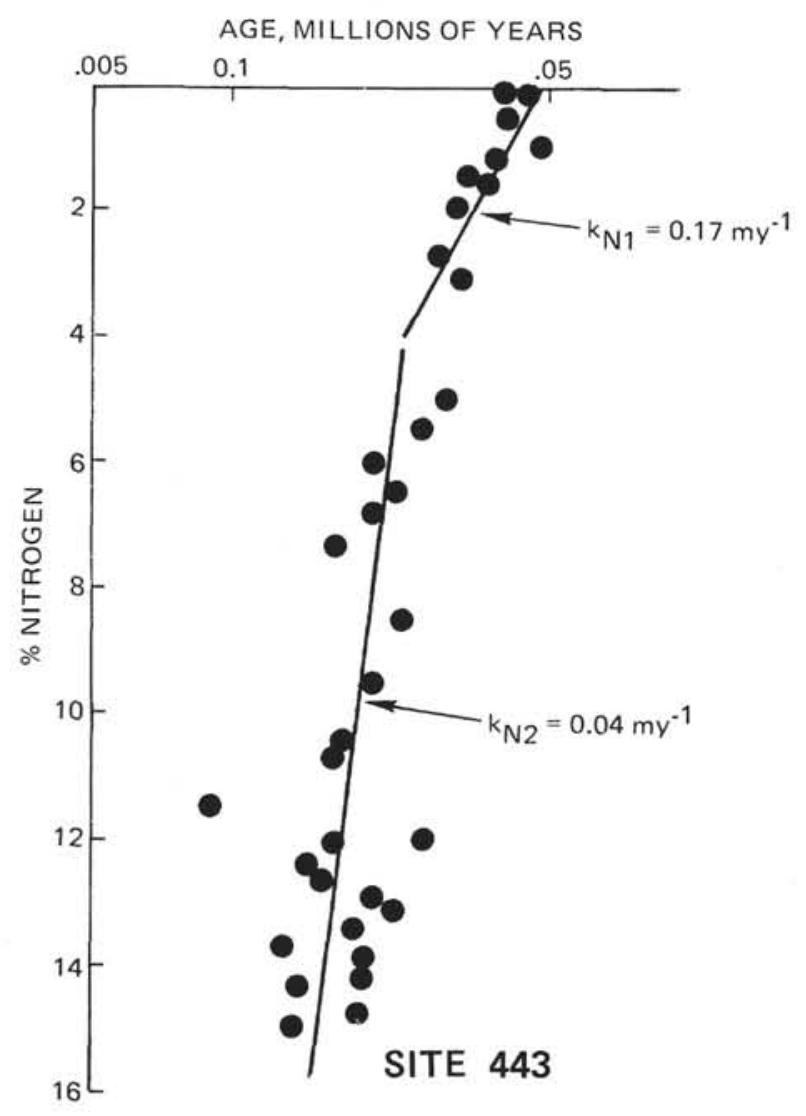

Figure 4. Semi-log kinetic plot of nitrogen content versus sediment age for Site 443 samples. ent analysis, but some of the sediments affected by igneous activity have been examined elsewhere (Waples, this volume). The deepest recovered hemipelagic sediments were only about $750 \mathrm{~m}$ below the sea floor. There is no evidence for unusually high geothermal gradients in the past, and, except as noted, no igneous intrusives were found.

\section{Bacterial Degradation}

\section{Nature of the Sediments}

Sediments from abyssal depths in the ocean are normally highly oxidizing (Baas Becking et al., 1960). According to those authors, Eh values in abyssal sediments are generally greater than $+390 \mathrm{mV}$ near the sediment/water interface, and they increase downward through the sediment column.

Our samples are very similar in appearance to those described by Baas Becking et al. Colors are variously tan, brown, red, green, and gray; black sediments are conspicuously absent. Some finely disseminated black material is sporadically present, but it consists of manganese micronodules. There are no indications of organic-rich material that could be responsible for highly reducing conditions. Extensive bioturbation has occurred in many of the sediments, indicating further that these sediments were deposited under aerobic conditions. Finally, Joris Gieskes (pers. comm.) noted at most only slight sulfate reduction in the sediments; this suggests that anaerobic bacterial activity has not been significant. 


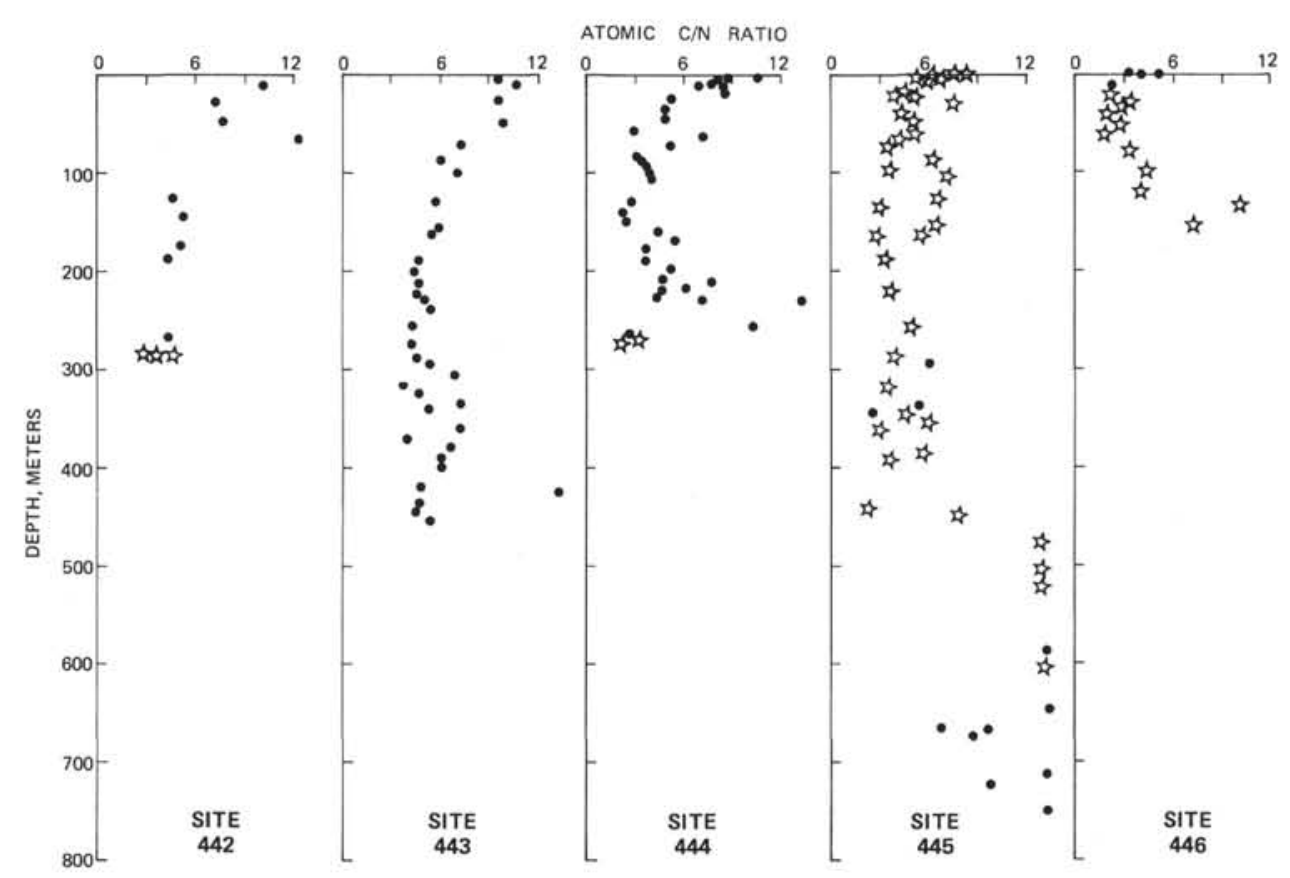

Figure 5. $C / N$ profiles for Leg 58 sediments. Circles represent hemipelagic sediments; stars represent pelagic sediments.

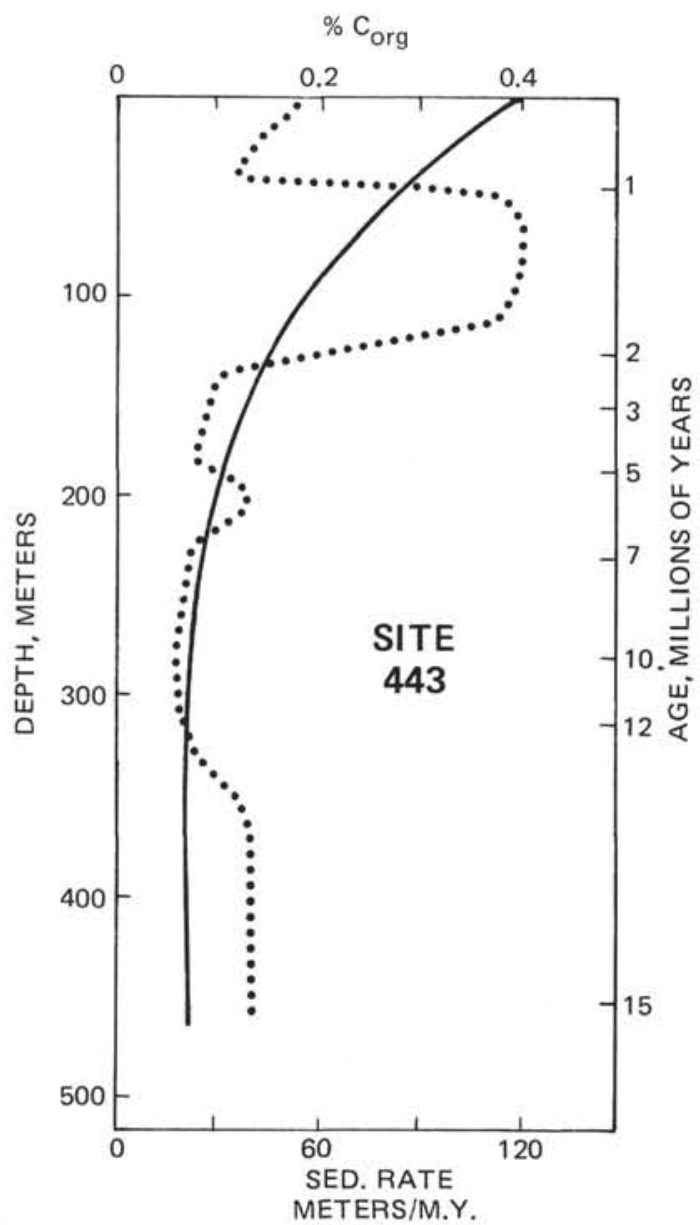

Figure 6. Sedimentation rate compared to organic-carbon content for Site 443 sediments. (Dotted line shows sedimentation rate.)
TABLE 7

Average Pleistocene Sedimentation Rates, and Rate Constants for Organic-Carbon and Nitrogen Loss for Leg 58 Sites

\begin{tabular}{cccc}
\hline Site & $\begin{array}{c}\text { Pleistocene Sedimentation Rate } \\
(\mathrm{m} / \mathrm{m} . \mathrm{y} .)\end{array}$ & $\begin{array}{c}k_{C} \\
\left(\mathrm{~m} . \mathrm{y}^{-1}\right)\end{array}$ & $\begin{array}{c}k_{N_{1}} \\
\left(\mathrm{~m} . \mathrm{y}^{-1}\right)\end{array}$ \\
\hline 443 & 60 & 0.8 & 0.17 \\
442 & 60 & 1.0 & 0.30 \\
445 & 25 & 1.1 & 0.28 \\
444 & 20 & 1.4 & 0.34 \\
\hline
\end{tabular}

Environmental conditions in the first few hundred meters of sediment appear to be favorable for at least some bacterial growth. Temperatures are low (probably less than $10^{\circ} \mathrm{C}$ ), and porosity of the sediments is high. Low organic-carbon content, on the other hand, may severely limit the bacteria population density within the sediments.

\section{Kinetics}

Kinetic data for loss of both organic carbon and nitrogen are consistent with bacterial decomposition of the organic material. Decomposition of an organic substrate by bacteria is generally first-order (Thimann, 1963) because carbon availability limits the rate of bacterial growth. Furthermore, the loss of carbon and loss of nitrogen by the first mechanism during the same time suggests that these two reactions are somehow linked. One possible explanation is that both carbon and nitrogen compounds are consumed by bacteria. At the end of approximately $5 \mathrm{~m} . \mathrm{y}$., all the organic material with nutritional value has been exhausted, and bacterial activity consequently ceases. The remaining organic compounds are refractory, and do not undergo further bacterial alteration (Figure 2). 
Nitrogen, however, is still present in relatively large quantities, and may be susceptible to non-bacterial degradation, with a first-order rate constant $k_{N_{2}}$, as shown by the lower portion of Figure 4 . In the upper part of the section, when bacterial activity is important, non-bacterial degradation of nitrogen is relatively insignificant, in keeping with the relative magnitudes of $k_{N_{1}}$ and $k_{N_{2}}$. In the absence of competing bacterial reactions, however, non-bacterial degradation operating over long periods of geological time apparently lowers the nitrogen content of these kerogens.

There is another condition under which bacterial activity could show a first-order kinetic dependence upon carbon, even under conditions where carbon is not the limiting reagent. For bacterial growth to occur, both an organic substrate and an electron acceptor (for example, oxygen, nitrate, or sulfate ion) must be present. If we assume a closed system (diffusion of the electron acceptor from outside sources is not important), then the concentration of the electron acceptor $A$ at any time $t$ will be given by the equation

$$
[A]_{t}=[A]_{o}-n \Delta \mathrm{C}_{\text {org }}
$$

where $[A]_{o}$ is the initial concentration of the electron acceptor, and $n$ represents the stoichiometric consumption of organic carbon compared to $A$. Since

$$
\Delta \mathrm{C}_{\text {org }}=\left[\mathrm{C}_{\text {org }}\right]_{o}-\left[\mathrm{C}_{\text {org }}\right]_{t}
$$

and since $[A]_{o}$ and $\left[\mathrm{C}_{\text {org }}\right]_{o}$ are constants, we have

$$
[A]_{t}=n\left[\mathrm{C}_{\mathrm{org}}\right]_{t}+\text { constant } .
$$

At any time, therefore, the concentration of the electron acceptor $A$ is proportional to the organic-carbon content of the sediment.

Under conditions where the electron acceptor $A$ is the limiting reagent, the rate of utilization of $A$ will depend upon the rate of diffusion of $A$ to the organic substrate. The rate of diffusion of $A$ depends directly upon the concentration of $A$, which in turn depends, as we have shown, on organic-carbon content.

The kinetics of bacterial decomposition of organic carbon will thus be first-order in carbon, even though carbon is neither the limiting reagent nor a participant in the rate-determining step. We therefore have at least two distinct cases where the rate of loss of organic carbon would be first-order in organic carbon. A bacterial degradation mechanism is thus capable of explaining the observed kinetics of both carbon and nitrogen loss.

\section{Nutrient Value of Sedimented Organic Material}

A problem with the bacterial-degradation hypothesis arises when we consider the nutritional value of the sedimented organic material at abyssal depths. These organic materials have arrived at the bottom only after a very difficult journey from the photic zone through a 3-mile water column. During this descent, which may have taken months or years, the material passed through many biofilters, each of which extracted some of the nutritional value from the debris before excreting the remainder. By the time the organic particles reached the bottom, most of the food value should have been extracted. However, if bacterial degradation were responsible for the loss of organic carbon observed in the Leg 58 sediments (from about $0.4 \%$ to $0.1 \%$ ), this would imply that at least 75 per cent of the organic material reaching abyssal depths still had nutritional value.

Recent studies on sedimentation of organic materials from the photic zone support the notion that a higher proportion reaches the deep ocean floor than was previously thought. Organic material descends through the water column not as small particles, but as relatively large fecal pellets of shallow-water herbivores (Schrader, 1971; Honjo, 1976). The consequent high settling rate would allow less time for reingestion by other organisms, and less time for bacteria to degrade the organic compounds before they reach the bottom; therefore, a greater amount of organic material with nutritional value would reach the ocean floor. Furthermore, as Jean Whelan (pers. comm.) has suggested, the benthic bacterial population may be adjusted to a supply of nutrient-poor organic material.

\section{Depth of Bacterial Activity}

Many workers (e.g., Emery and Rittenberg, 1952) have noted that bacterial activity is highest just below the sediment/water interface, and then drops off very rapidly with increasing sediment depth, reaching very low values at depths of a few meters. However, other recent work (Whelan, in press; Claypool, 1974; Claypool and Kaplan, 1974) suggests that methane in abyssal sediments at depths of several hundred meters may be biogenic. If this view is correct, then the sediments studied in the present work should be within the depth range of bacterial degradation.

Whelan based her conclusions on $\mathrm{C}_{1}$ to $\mathrm{C}_{5}$ compositions, on ${ }^{13} \mathrm{C}$ measurements for methane, and on changes in pore-water chemistry of gassy cores recovered on DSDP Leg 56. Claypool (1974) cited numerous parallel changes in organic and inorganic components of pore water as evidence of biological activity in deep-sea sediments. Curves of sulfate and bicarbonate depletion indicate the existence of a sequence of zones of anaerobes. Carbon-isotope ratios support the hypothesis that dissolved methane in deep (up to $750 \mathrm{~m}$ ) cores is biogenic, and that bicarbonate is being consumed via a reaction with a strong preference for ${ }^{12} \mathrm{C}$ (bacterial reduction to $\mathrm{CH}_{4}$ ). No satisfactory alternative hypothesis which can explain these findings has been proposed. In light of the present data, therefore, it appears possible that anaerobic bacterial activity can extend hundreds of meters into the sedimentary column.

In reality, there is no necessary discrepancy between the two points of view on bacterial activity in deep sediments. It is an established fact that the size of bacterial populations decreases by many orders of magnitude in the first few meters of sediment. On the other hand, no one maintains that there is a total absence of bacteria below the first few meters. 
Calculations (Tsou et al., 1973) indicate that the rates of bacterial metabolism at depths greater than a few meters must be very slow $\left(10^{-8}\right.$ moles liter $\left.^{-1} \mathrm{yr}^{-1}\right)$ to produce the noted small effects over the long time periods available. It would seem, therefore, that the presence of relatively small numbers of bacteria, coupled with the greatly reduced metabolic rates noted by Jannasch and Wirsen (1977) for barotolerant bacteria, could readily account for the slow but steady destruction of organic material in deep-sea sediments.

\section{Time}

Another criticism of the bacterial-degradation hypothesis comes from an ecosystem analysis. One principle of ecology is that, in a stable ecosystem, every habitat will be filled, and all sources of energy and nutrition will be utilized efficiently. The abyssal ecosystems encountered in Leg 58 sediments are isolated from external stimuli, and therefore ought to be very stable. The complex biofilter system in the overlying water column guarantees that the supply of organic material will be uniform. The abyssal depths are almost completely out of contact with climatological events at sea level, and bottom currents appear to be rather uniform through time, especially in offshore basins.

The implications of this principle for bacterial ecosystems at abyssal depths are significant. From Figure 1 it appears that about $5 \mathrm{~m} . \mathrm{y}$. are required to effect the maximum degradation of organic carbon in these sediments. This length of time is several orders of magnitude greater than that required for extensive bacterial decomposition in other environments (e.g., eutrophic lakes, bogs, near-shore marine sediments), and is in apparent contradiction with the ecological principle outlined above. If a given quantity of bacteria could accomplish the degradation in $5 \mathrm{~m}$.y., why is the number of bacteria not increased and the degradation accomplished in a much shorter time? This is what would be expected in a natural ecosystem.

It has been noted by Jannasch and Wirsen (1977) that bacterial activity at abyssal depths proceeds about two orders of magnitude slower than at surface conditions. At first glance, it appears that the absolute slowness of bacterial metabolism at abyssal depths might explain the 5-m.y. degradation time, but it does not. While it is true that slower metabolism could readily explain why an abyssal ecosystem would take much longer to re-establish equilibrium after a traumatic event, it cannot alter the essential features of an equilibrium ecosystem. That is, even if each individual bacterium consumes nutrients at a much slower rate than in near-surface environments, all that is necessary to achieve the near-surface rate of consumption is an increase in the total number of bacteria. Since the bacterial populations are likely to be very small, a hundredfold or thousandfold increase probably would cause no difficulties.

Perhaps the best way to resolve this dilemma is to assume that bacterial activity does occur at very slow rates in deeply buried sediments, but that the slowness of their activity is only in apparent violation of the aforementioned ecological principle. This implies that the bacterial population in the sediments is the largest possible, and that the rate of consumption of organic material is the fastest possible. The rate of consumption of organic material may be limited by the rate of diffusion of required electron acceptors within the sediments, or by some other non-biological rate-limiting step.

\section{CONCLUSIONS}

Organic-carbon and nitrogen decrease in the first 50 to 200 meters of burial, and then remain constant at very low values throughout the lower part of the section. The decrease appears to be related to bacterial diagenesis of the organic material. This observation suggests that bacterial diagenesis in this particular abyssal ecosystem occurs at much greater depths (up to 200 meters) and over much longer times (up to 5 m.y.) than has previously been accepted for such environments.

The abyssal ecosystem must be very stable, isolated as it is from external stimuli, and according to the precepts of ecology, therefore must represent the most efficient utilization of nutrients. The long times required for complete bacterial utilization of organic material suggest that bacterial populations must be very small, and therefore that the rate of utilization is limited by some essential nutrient other than organic carbon. A model is proposed in which the diffusion of the required electron acceptor is the rate-limiting process. This conclusion is compatible both with the observed first-order kinetic dependence of carbon disappearance on organiccarbon content, and with the observation that carbon and nitrogen consumption occur most rapidly where sedimentation rates are low.

\section{ACKNOWLEDGMENT}

We thank Lisa Buurma and Jay Horvath for technical assistance; our shipboard colleagues for many stimulating discussions; and George Claypool, Jean Whelan, and Dave Updegraff for helpful comments on the manuscript.

\section{REFERENCES}

Bass Becking, L. G. M., Kaplan, I. R., and Moore, D. 1960. Limits of the natural environment in terms of $\mathrm{pH}$ and oxication-reduction potentials, J. Geol., 68, 243-284.

Berner, R. A., 1978. Sulfate reduction and the rate of deposition of marine sediments. Earth Planet. Sci. Lett., 37, 492.

Claypool, G., 1974. Anoxic diagenesis and bacterial methane production in deep sea sediments. Unpublished Ph.D. Thesis, UCLA, 276 pp.

Claypool, G. and Kaplan, I. R., 1974. The origin and distribution of methane in marine sediments. In Kaplan, I. R. (Ed.), Natural Gases in Marine Sediments: New York (Plenum). 99-139.

Emery, K. O. and Rittenberg, S. C., 1952. Early diagenesis of California basin sediments in relation to origin of oil. Bull. Am. Assoc. Petrol. Geol., 36, 735-806.

Goldhaber, M. B. and Kaplan, I. R., 1975. Controls and consequences of sulfate reduction rates in recent marine sediments. Soil Sci., 119, 42-55.

Honjo, S., 1976. Coccoliths: production, transportation, and sedimentation. Mar. Micropaleo. 1, 65-79.

Jannasch, H. W. and Wirsen, C. O., 1977. Microbial life in the deep sea. Sci. Am. 236, (6), 42-52. 
Schrader, H. J., 1971. Fecal pellets: role in sedimentation of pelagic diatoms. Science $174,55-57$.

Thimann, K. V., 1963. The Life of Bacteria: New York (MacMillan).

Toth, D. J. and.Lerman, A., 1977. Organic matter reaction and sedimentation rates in the ocean. Am. J. Sci., 277, 465-485.

Tsou, J. L., Hammond, D., and Horwitz, R., 1973. Institutional water studies, Leg 15 -Study of $\mathrm{CO}_{2}$ released from stored deep sea sediments. In Heezen, B. C., MacGregor, I. D., et al., Init. Repts. DSDP 20: Washington (U. S. Govt.Printing Office), 851-863.

Waples, D. W., 1977. $\mathrm{C} / \mathrm{N}$ ratios in source rock studies. Colorado School of Mines Mineral Ind. Bull., 20, (5), 1-7.

Whelan, J., in press. Gas-chromatography-pyrolysis thermal distillation of Oligocene-Cretaceous sediments, Deep Sea Drilling Project Sites 438 and 439. In Langseth, M., Okada, H., et al., Init. Repts. DSDP, 56, 57, Pt. 2: Washington (U, S, Govt. Printing Office).

\section{APPENDIX 1}

\section{Analytical Methods}

Prior to combustion analysis for organic carbon, carbonate was removed by treatment with acid. Five $\mathrm{ml}$ of concentrated $\mathrm{HCl}$ was added to about 5 grams of wet sediment. If effervescence was strong, more $\mathrm{HCl}$ was added after bubbling had ceased, to assure that all carbonate was destroyed. The aqueous $\mathrm{HCl}$ was then evaporated overnight at $40^{\circ} \mathrm{C}$ in a drying oven. The dry, carbonate-free sediment was then ground with mortar and pestle, weighed on a gimbled Cahn electrobalance, and analyzed on a Hewlett-Packard 185B CHN analyzer. Duplicate samples were run periodically, and always gave close agreement. The absolute organic-carbon content of the sediments was calculated aboard ship from the Archaean Greenstone Standard (AGS). This standard was excellent for the Leg 58 samples, because of their low carbon contents.

Nitrogen content was calculated from an acetanilide/sand standard. Acetanilide contains eight carbon atoms for each nitrogen, so it was possible to calculate relative atomic-response factors. Since the absolute carbon-response factor was known from the AGS, the absolute nitrogen content of the samples could be calculated.

The advantage of our procedure for carbonate removal is that labile organic carbon, a common feature of organic matter in recent sediments, is not lost through decantation and washing. Furthermore, a mathematical correction for change in sample mass during carbonate removal and drying may be made if desired, according to equation (1).

$$
\begin{aligned}
& \mathrm{CaCO}_{3}(\mathrm{~s})+2 \mathrm{HCl}-\mathrm{CaCl}_{2}(\mathrm{~s})+\mathrm{H}_{2} \mathrm{O} \mathrm{I}+\mathrm{CO}_{2} \uparrow \\
& M=100 \quad M=111
\end{aligned}
$$

For samples containing 10 per cent $\mathrm{CaCO}_{3}$ by weight, the change in total sample weight after carbonate removal is only 1 per cent, well within the accuracy of the analysis. No correction was necessary for most of the Leg 58 samples.

\section{APPENDIX 2 \\ Calculation of First-Order Rate Constants for Loss of Organic Carbon and Nitrogen}

If the loss of organic carbon (C) follows a first-order rate law, then

$$
\stackrel{-d[C]}{d t}=k_{c}[\mathrm{C}]
$$

Integration gives

$$
\ln [\mathrm{C}]_{t}=-k_{c} t+\ln [\mathrm{C}]_{o} .
$$

where $[\mathrm{C}]_{o}$ is the initial concentration of reactive kerogen, $[\mathrm{C}]_{t}$ is the remaining concentration of reactive kerogen at any time, $t$ (expressed in m.y.), and $k_{c}$ is the first-order rate constant for loss of organic carbon. The value of $k_{c}$ can be obtained from the slope of a plot of $[C]_{t}$ versus $t$ (Figure 2).

It must be noted, however, that apparently not all kerogen present is reactive, since loss of organic carbon ceases before all the carbon has been consumed. From Figure 1 it can be seen that for Site 444, for example, the carbon content drops to 0.06 per cent and then remains constant. It is therefore assumed that 0.06 per cent represents the unreactive carbon at Site 444 . Therefore 0.06 per cent must be subtracted from the total organic carbon for each sample at this site in order to calculate the concentration of reactive carbon. (Example: In Figure 1, for Site 444 , the highest $\mathrm{C}_{\text {org }}$ content is 0.32 per cent. Of this total $\mathrm{C}_{\text {org }}$, therefore, 0.06 per cent is unreactive and 0.26 per cent is reactive.)

The rate constants for nitrogen depletion are calculated analogously, by substituting $\mathrm{N}$ for $\mathrm{C}$ in equations (1) and (2). All nitrogen, however, was considered to be reactive, since nitrogen loss persisted throughout the section. 